\title{
НАУКОВІ СТАТТI
}

\section{Соціально-економічні проблеми Донбасу}

\author{
doi: 10.12958/1817-3772-2020-2(60)-4-9 \\ Т. Ю. Коритько, \\ кандидат економічних наук, \\ ORCID 0000-0002-4251-1971, \\ taniakorytko@gmail.com,
}

Інститут економіки промисловості НАН Украӥни, м. Київ,

Н. В. Осадча,
доктор економічних наук,
ORCD 0000-0001-5066-2174,
Інститут економіки промисловості НАН України, м. Дніпро,

Г. Ф. Толмачова,

кандидат економічних наук, anna_iep@ukr.net,

Інститут економіки промисловості НАН України, м. Київ

\section{ПРОБЛЕМИ РОЗВИТКУ МАЛОГО ТА СЕРЕДНЬОГО БІЗНЕСУ}

Постановка проблеми. Становлення ринкових відносин в економіці України, їі стійке економічне зростання багато в чому пов'язане з розвитком малого підприємництва. Як показує досвід економічно розвинених країн, мале підприємництво відіграє винятково важливу роль в економічному і соціальному житті суспільства. На його частку припадає до 5070\% валового внутрішнього продукту економічно розвинених країн, частка малих фірм становить до 80-90\% від загального числа комерційних організацій.

Малий бізнес як соціально-економічне явище зачіпає безліч об’єктів і породжує між ними певні зв’язки (структурні, функціональні, організаційні, ресурсні та технологічні), що дозволяє досліджувати його розвиток з точки зору системного аналізу. У просторовому аспекті, будучи підсистемою регіону, малий бізнес здатний швидко реагувати на економічні зміни, обслуговувати вузькі і специфічні сегменти ринку i легко адаптуватися під «нові умови функціонування економічних сегментів», сприяючи швидкому перерозподілу ресурсів в економічній системі. Матеріальні та фінансові обмеження стимулюють малий бізнес шукати конкурентоспроможні переваги в когнітивному потенціалі наявних можливостей. Динамічний і сталий розвиток даного сектору економіки регіону направлено на формування ефективного конкурентного середовища та підвищення якості життя населення.

Специфічна сутність малого бізнесу, наділеного як сильними, так і слабкими сторонами, зумовлює необхідність у державній підтримці, оскільки остання хоча і $є$ фактором зовнішнього середовища, але виконує фільтраційну функцію, спрямовану на нейтралізацію негативного впливу одних факторів зовнішнього середовища і посилення позитивного впливу інших.

Аналіз останніх досліджень і публікацій. Серед вітчизняних дослідників проблем розвитку малого та середнього підприємництва можна виділити роботи: А. Бутенка [1], В. Ляшенка [2], С. Жукова [3], Г. Толмачової [4; 5] та ін. Однак в сучасних умовах реформування економіки виникає необхідність поглибленого дослідження проблем та перспектив розвитку малого бізнесу, що дозволить розробити комплекс заходів щодо забезпечення його розвитку.

Метою статті $\epsilon$ дослідження проблем, перспектив малого підприємництва в Україні, визначення шляхів забезпечення його розвитку.

Систематичний аналіз форм, методів та інструментів взаємодії кожної з підсистем зовнішнього середовища 3 підприємницькою структурою дозволить оцінити поточний стан неоднорідного середовища, виявити 3 невизначених і мінливих стратегічні чинники, що сприяють (можливості) або перешкоджають (загрози) досягненню цілей підприємницької структури, скорегувати або розробити адекватну на них реакцію 3 боку підприємницької структури, що буде визначати модель ії поведінки у зовнішньому середовищі як активну. Активна модель передбачає, в свою чергу, необхідність прогнозувати можливі ситуації на ринку, поведінку і характер впливу обраних стратегічних факторів середовища на підприємницьку діяльність, підвищення гнучкості самої підприємницької структури, побудову імітаційних моделей, трендів, програм конкретних дій по відношенню до суб'єктів середовища, тобто управляти ними.

Зовнішнє середовище малого і середнього підприємництва Донецької області включає такі під- 
системи: економічну, політичну, правову, соціально-демографічну, науково-технічну й інституційно-організаційну, кожна $з$ яких у свою чергу характеризується системою відповідних показників. Проведений аналіз показав, що щорічно за період 2015-2018 pр. кількість середніх і малих підприємств в Донецькій області знижується на $17,22 \%$. За даний період чисельність зайнятих у середньому та малому підприємництві знизилася на 16,7\%. Також в цьому році відзначений інтенсивний приріст обсягів реалізації середніх і малих підприємств - на 15,91\%. Протягом аналізованого періоду детальність середніх та малих підприємств є збитковою, так в 2018 р. фінансовий результат до оподаткування підприємств зменшився на 19560266 тис. грн порівняно з 2015 р.

На основі використання PEST-аналізу проведемо узагальнення зовнішніх факторів, що впливають на діяльність малих підприємств (табл. 2).

Таблиияя 1

Основні показники підсистеми зовнішнього підприємницького середовища Донецької області за 2015-2018 рр.

\begin{tabular}{|l|c|c|c|c|}
\hline \multicolumn{1}{|c|}{ Показники } & 2015 & 2016 & 2017 & 2018 \\
\hline Кількість суб’єктів господарювання, одиниць & 11723 & 10451 & 10423 & 9704 \\
\hline Кількість зайнятих працівників, осіб & 202094 & 188038 & 161362 & 168342 \\
\hline Обсяг реалізованої продукції, тис. грн & 108840582,9 & 112834669,7 & 125591517,4 & 126160715,3 \\
\hline Фінансовий результат до оподаткування, тис. грн & $-25211568,4$ & $-12967039,6$ & $-3782107,6$ & $-5651302,6$ \\
\hline Валовий регіональний продукт, млн грн & 115012 & 137500 & 166404 & 192256 \\
\hline
\end{tabular}

\section{PEST-аналіз середніх та малих підприсмств Донецької області [6; 7]}

Таблиияя 2

\begin{tabular}{|c|c|}
\hline Політичні фактори & Економічні фактори \\
\hline $\begin{array}{l}\text { 1. Військові дії на сході України та анексія Криму. } \\
\text { 2. Активізація співпраці } 3 \text { країнами Свропей- } \\
\text { ського Союзу. } \\
\text { 3. Погіршення торгівельних стосунків з Росією та ін- } \\
\text { шими країнами СНД. } \\
\text { 4. У зв’язку зі вступом до СОТ можливості дер- } \\
\text { жавного регулювання в питаннях стосовно конкуренції } \\
\text { значно обмежені. } \\
\text { 5. Законодавчі пільги для заохочення інноваційної дія- } \\
\text { льності }\end{array}$ & $\begin{array}{l}\text { 1. Негативні тенденції в розвитку економіки України та } \\
\text { Донецької області. } \\
\text { 2. Низький платоспроможний попит на внутрішньому } \\
\text { ринку. } \\
\text { 3. Відсутність належної державної підтримки МСБ. } \\
\text { 4. Недосконала податкова та митна політика. } \\
\text { 5. Недостатність інвестицій та фінансових ресурсів. } \\
\text { 6. Низька інноваційна активність }\end{array}$ \\
\hline $\begin{array}{c}\text { Соціальні фактори } \\
\end{array}$ & Технологічні фактори \\
\hline $\begin{array}{l}\text { 1. Зменшення кількості працездатного населення. } \\
\text { 2. Відтік кваліфікованого персоналу за кордон та в інші } \\
\text { галузі. } \\
\text { 3. Недостатня кількість кваліфікованого управлін- } \\
\text { ського, інженерно-технічного та виробничого персо- } \\
\text { налу. } \\
\text { 4. Недостатній рівень оплати та мотивації праці в га- } \\
\text { лузі. } \\
\text { 5. Відсутність належного кадрового резерву }\end{array}$ & $\begin{array}{l}\text { 1. Низький рівень конкурентоспроможності галузі через } \\
\text { технологічне відставання. } \\
\text { 2. Високий рівень зношеності основних фондів. } \\
\text { 3. Залежність від поставок сировини та комплектуючих з } \\
\text { інших підприємств чи інших країн. } \\
\text { 4. Випуск нових видів продукції. } \\
\text { 5. Впровадження енергозберігаючих та природо- охорон- } \\
\text { них заходів. } \\
\text { 6. Відповідність організації виробництва умовам ринко- } \\
\text { вого середовища }\end{array}$ \\
\hline
\end{tabular}

1. Політичні фактори (P - political).

1.1 Проведення військових дій на сході України. Політична ситуація, яка склалася на Донбасі призвела до втрати російського ринку та зменшення поставок до різних країн СНД, а також до втрати частини експортних потужностей за рахунок скорочення чисельності підприємств на 2019 одиниць у 2018 р. порівняно з 2015 р.

1.2 Розширення співпраці з країнами ЄС. Підписання Угоди про асоціацію між Україною і Свропейським Союзом, а також введення в дію з боку СС односторонніх торгових преференцій для України 3 квітня 2014 р. не сприяло збільшенню обсягу експорту окремих видів продукції та зменшенню від'ємного сальдо зовнішньої торгівлі Донецької області з країнами ЄС. У 2018 р. від’ємне сальдо зовнішньої торгівлі Донецької області з країнами ЄС склало 2148,2 млн дол. США, що на 3702,4 млн дол. США більше порівняно з 2015 р.

\section{2. Економічні фактори ( $\mathrm{E}$ - economic).}

2.1 Несприятливі економічні умови для розвитку економіки України та Донецької області. Критеріями розвитку й успіху справ у середньому та малому підприємництві $є$ рівень доходів і кількість охочих займатися середнім та малим бізнесом. В Донецькій області у 2015 р. 11,7 тис., а у 2018 р. їх кількість скоротилася та склала 9,7 тис. підприємств, тобто частка малого бізнесу у 2018 р. склала 94,5\%.

2.2 Відсутність належної підтримки проведення структурно-технологічної модернізації підприємств малого та середнього бізнесу. Основні документи, що формують державну політику у сфері статистики МСП, - це Стратегія розвитку статистики до 2017 року [8] та Стратегія розвитку малого 
й середнього підприємництва в Україні на період до 2020 року [8]. Незважаючи на те, що відносини в сфері малого підприємництва регулюються значною кількістю законодавчих актів: законами України, указами Президента України, постановами та розпорядженнями Кабінету Міністрів України, в умовах економічних криз цей вид діяльності потребує більшої правової підтримки, що сприяло б подальшому розвитку малого підприємництва як на рівні країни в цілому, так і на рівні окремих іiї регіонів.

Важливу роль у підвищенні ефективності малого бізнесу в межах регіону належить місцевим органам влади. Малі підприємства, як найбільш численна, динамічна та гнучка форма бізнесу відіграють значну роль у соціально-економічному розвитку. В сучасних умовах не спостерігається очікуваної результативності малого бізнесу в економіці як країни, так і регіону. В Донецькій області недостатньо залучаються до реалізації інвестиційних проєктів малі та середні підприємства.

2.3 Низька інноваційна активність. Відсутність дієвих стимулів для інноваційної діяльності спричиняє низьку сприйнятливість підприємств до інновацій, що загрожує нарощуванням технологічного та інноваційного відставання підприємств МСБ Донецької області від розвинутих країн, гальмуванням структурних перетворень в економіці, подальшою втратою її конкурентоспроможності. Відсутність дієвих стимулів для інноваційної діяльності спричиняє низьку сприйнятливість підприємств до інновацій, що загрожує нарощуванням технологічного та інноваційного відставання Донецької області від розвинутих країн, гальмуванням структурних перетворень в економіці. Аналіз статистичних даних наукової та інноваційної діяльності в Донецькій області показав, що протягом 2015-2018 рр. частка підприємств, що впроваджували інновації, коливалась від 11\% [10], а частка витрат на виконання наукових досліджень і розробок у ВРП Донецької області у 2018 р. склала 0,0084\%, що на 0,006 в.п. менше, ніж y 2015 p.

2.4 Недосконала податкова політика. Незважаючи на проведення реформи податкової системи, яка розпочалася у 2011 р. в Україні зафіксовані такі ставки податків: податок на прибуток - 18\%, єдиний соціальний внесок роботодавця - 22\%, податок на доходи фізичних осіб - 18\%, ПДВ - 20\%, а також ПДВ для фармакологічної продукції у розмірі 7\% та $0 \%$ для експортерів. Крім того, у зв'язку з появою додаткових непередбачуваних видатків на проведення АТО/ООС урядом було введено обов'язковий військовий збір у розмірі 1,5\% [11]. Отже, виходом для країни є спрощення податкової системи з метою стимулювання міжнародних компаній/інститутів працювати в даному середовищі, поступова інтеграція податкового законодавства в європейське, створення більш дієвих методів боротьби 3 корупцією. Як приклад можна взяти досвід Китаю щодо вдосконалення системи податкового регулювання шляхом упровадження сучасних інформаційних систем моніторингу [12].

2.5 Недостатність обсягу інвестування. У цілому обсяг капітальних інвестицій у підприємства Донецької області у 2018 р. порівняно з 2015 р. зріс на 18675 млн грн [10]. Однак наявного обсягу капітальних інвестицій недостатньо для повноцінної технологічної модернізації підприємств МСБ.

2.6 Висока облікова ставка НБУ, високі ставки кредитування комерційних банків. Соціально-економічна нестабільність призвела до того, що Національний банк України був змушений проводити дуже жорстку грошово-кредитну політику, що призвела до підвищення процентних ставок. У даний час середньозважена процентна ставка складає 13,5\%, що виступає негативним фактором при міжнародному зіставленні. Високі процентні ставки здійснюють негативний вплив на підприємства МСБ, який проявляється у скороченні обсягів інвестицій та зниженні рівня міжнародної конкурентоспроможності, що призведе до зниження попиту на продукцію та послуги як на внутрішньому, так і на зовнішньому ринку.

3. Соціальні фактори (S - social). У 2018 р. порівняно з 2015 р. спостерігається зростання рівня економічної активності населення з 69,0 до 69,5\%, так кількість економічно активного населення скоротилася з 872,9 тис. чол. у 2015 р. до 834,7 тис. чол. у 2018 р. Рівень безробіття в Донецькій області збільшився у 2018 р. порівняно з 2015 р. $з$ 14,4\% до $15,2 \%[10]$.

Наявні статистичні дані засвідчують зростання середньомісячної номінальної заробітної плати у 2018 р. порівняно з 2015 р. на 94,5\%, з 4980 грн до 9686 грн, але темп зростання реальної заробітної плати склав 89,6\% у 2015 р. до попереднього року, а у 2018 р. темп приросту реальної заробітної плати склав $10,2 \%$.

4. Технологічні фактори ( $\mathrm{T}$ - technological). Технологічні фактори дають змогу виявити тенденції технологічного розвитку підприємства, забезпечити підприємство інформацією щодо вчасного реагування на нові розробки в науці та техніці.

3 встановлених технологічних факторів випливає, що потрібно кардинально змінити вектори інноваційної політики, спрямувавши їх на активізацію інноваційних процесів на підприємствах, підвищення рівня створення та використання передових технологій, оцінити інноваційні можливості машинобудівних підприємств та розробити на цій основі заходи з підвищення інвестиційної активності, розробити і реалізувати програми дій з відновлення активної частини основних фондів, стимулювати впровадження сучасних методів менеджменту.

На основі отриманих результатів можна зазначити, що малий і середній бізнес, звичайно, не завжди може скласти конкуренцію великим підприємствам, тому що у власності регіональних та місцевих органів влади немає достатньої кількості вільних 
площ, які можуть бути надані на пільгових умовах малому бізнесу. Для малих підприємців нездоланним адміністративним бар'єром стає участь в державному замовленні, тоді як великим підприємствам легше гарантувати виконання більш вигідних умов. Складнощі у малого і середнього бізнесу порівняно з великими підприємствами в регіоні складаються із отриманням кредитів, а також при оформленні лізингових угод, оскільки у суб'єктів малого підприємництва відсутній достатній обсяг заставного забезпечення та кредитна історія. Підприємціпочатківці часто не уявляють всіх труднощів, які пов’язані з веденням бізнесу, яке вимагає професійних знань, знань по веденню бухгалтерського обліку та звітності, з менеджменту та маркетингу.

Для визначення проблем у розвитку підприємств МСБ необхідно провести оцінку на основі SWOT-аналізу. Даний метод дозволяє провести оцінку сильних та слабких сторін внутрішнього середовища відносно можливостей та загроз зовнішнього середовища та проаналізувати вплив факторів на розвиток діяльності підприємств МСБ. Матриця SWOT-аналізу підприємств МСБ Донецької області, яка дозволяє визначити можливі напрями розвитку їх діяльності в сучасних умовах наведена у табл. 3.

SWOT-аналіз підприємств МСБ Донецької області [13; 14]

Таблиия 3

\begin{tabular}{|c|c|}
\hline Можливості & Загрози \\
\hline $\begin{array}{l}\text { 1. Наявність промислового комплексу. } \\
\text { 2. Високий науково-освітній та дослідницький потен- } \\
\text { ціал. } \\
\text { 3. Вигідне географічне розташування. } \\
\text { 4. Активне використання потенціалу: природних ресур- } \\
\text { сів, науково-технічних кадрів і т.п. } \\
\text { 5. Створення науково-технічних центрів. } \\
\text { 6. Мобільність в організації малих підприємств }\end{array}$ & $\begin{array}{l}\text { 1. Несприятлива макроекономічна ситуація. } \\
\text { 2. Недостатня обізнаність підприємців з чинним законо- } \\
\text { давством, оподаткуванням, відсутність управлінського } \\
\text { досвіду. } \\
\text { 3. Відсутність довгострокового кредитування. } \\
\text { 4. Слабкий фінансовий потенціал. } \\
\text { 5. Зростання цін на сировину та енергоресурси. } \\
\text { 6. Слабка ланка держзамовлень і коопераційних зав’яз- } \\
\text { ків з великими підприємствами. } \\
\text { 7. Низька купівельна спроможність }\end{array}$ \\
\hline Сильні сторони & Слабкі сторони \\
\hline $\begin{array}{l}\text { 1. Легка реєстрація бізнесу. } \\
\text { 2. Високоякісний людський капітал. } \\
\text { 3. Можливість пожвавлення внутрішнього ринку. } \\
\text { 4. Мале підприємство адаптивне та оперативно реагує } \\
\text { на зміни кон'юнктури ринку. } \\
\text { 5. Орієнтується на місцевий ринок та індивідуальне спо- } \\
\text { живання. } \\
\text { 6. Створює робочі місця. } \\
\text { 7. Спрощена система управління, швидке прийняття рі- } \\
\text { шень }\end{array}$ & $\begin{array}{l}\text { 1. Високий рівень інфляційних ризиків кредитування. } \\
\text { 2. Технологічна обмеженість виробництва, необхідність } \\
\text { переозброєння та модернізації. } \\
\text { 3. Нестабільність ринку енергоресурсів. } \\
\text { 4. Нестабільне законодавство. } \\
\text { 5. Недосконалий рівень конкурентоспроможності ма- } \\
\text { лих підприємств. } \\
\text { 6. Низька диверсифікація експорту }\end{array}$ \\
\hline
\end{tabular}

На основі табл. 3 можна зазначити, що аналіз макрорівня і чинників зовнішнього середовища діяльності підприємств показує, що економіко-політична ситуація на ринку, що характеризується істотною залежністю підприємств від зарубіжних постачань продукції, формує передумови для переорієнтації попиту на користь вітчизняної продукції на внутрішньому ринку Ключову роль в підвищенні конкурентоспроможності підприємств МСБ відіграють підприємства, діяльність яких має бути спрямована на технологічну модернізацію виробництва i підвищення конкурентоспроможності продукції, вдосконалення маркетингово-збутової політики, зниження витрат, диверсифікацію й інновації.

Висновок. За підсумками проведеного аналізу можна зробити висновок про те, що за останні кілька років суб'єкти малого підприємництва продовжують розвиватися, однак існують певні проблеми в їх діяльності. Для їх вирішення органи регіональної влади розробляють програми підтримки, надають субсидії, створюють фонди стимулювання суб’єктів малого підприємництва. Слід зазначити, що розвиток підприємницької активності можливий при по- слідовному зниженні рівня оподаткування, посиленні контрольних функцій держави та забезпеченні правоохоронними органами безпеки ведення малого бізнесу. Збільшення числа сумлінних платників податків виведе 3 тіні значні фінансові потоки, збільшить податкові надходження суб'єктів малого підприємництва до бюджетів різних рівнів. Таким чином, основними напрямками стимулювання діяльності малого підприємництва $є$ : удосконалення законодавчої бази, спрощення процесу реєстрації, реалізація інноваційної активності в різних сферах діяльності, збільшення обсягів фінансової підтримки, спрощення податкової системи і доступу малих підприємств до кредитних ресурсів.

\section{Література}

1. Бутенко А.І., Шлафман Н.Л. Напрямки дерегуляції діяльності малих підприємницьких структур в Україні. Вісник економічної науки Украӥни. 2012. № 1 (21). С. 30-33. 2. Модернізація механізмів розвитку малого та середнього бізнесу : моногр. / А.І. Бутенко, М.П. Войнаренко, В.І. Ляшенко та ін.; НАН України, Ін-т економіки пром-сті. Донецьк, 2011. 326 с. З. Жуков С., Дюгованець О., Балко О. Мале підприємни- 
цтво в Україні: роль, стан і перспективи розвитку в період соціально-економічних потрясінь. Вісник економічної науки України. 2019. № 1(36). С. 40-43. 4. Толмачова Г. Ф. Мале і середнє підприємництво як чинник виходу економіки Донбасу з кризи. Вісник економічної науки Украӥни. 2015. № 1. С. 146-154. 5. Толмачова Г.Ф., Ляшенко В.І., Колсснікова Г.В. Регулювання розвитку малого і середнього підприємництва: досвід зарубіжних країн для України. Економічний вісник Донбасу. 2017. № 1 (47). С. 157-185. 6. Болгарин П. Н., Ильяшенко С. Н. Анализ рыночных возможостей развития трубопрокатного произвосдтва на ПАО «СМНПО им. М.В. ФРУНЗЕ». Маркетинг $і$ менеджмент інновацій. 2013. №1. С. 13-33. 7. Стрільчук Р.М. Управління стратегічними можливостями машинобудівних підприємств : дис. ... канд. екон. наук : 08.00.04 / М-во освіти і науки України, Луцький нац. техн. ун-т. Луцьк, 2016. С. 226. 8. Стратегія розвитку статистики до 2017 року: Розпорядження КМУ від 20 березня 2013 року № 145-p. URL: http:// zakon2.rada.gov.ua/laws/ show/145-2013-\%D1\%80. 9. Стратегія розвитку малого й середнього підприємництва в Україні на період до 2020 року: Розпорядження КМУ від 24 травня 2017 року № 504-p. URL: http:// zakon2.rada.gov.ua/laws/ show/504-2017-\%D1\%80. 10. Головне управління статистики у Донецької області. URL: http://donetskstat. gov.ua/statinform1/index.php. 11. Податковий кодекс України: Закон України від 2 грудня 2010 р. № 2755VI. URL http://zakon3.rada. gov.ua/laws/show/275517/page4. 12. Організація виробничої та маркетингової діяльності малого і середнього бізнесу : монографія / за наук. ред. д.е.н., професора, академіка АЕНУ К. С. Жадька. Дніпро : УМСФ, 2019. 224 с. 13. ЧечетоваТерашвілі Т. М. Стратегічний аналіз розвитку малого підприємництва в Харкові. Бізнес Інформ. 2013. №8. С. 237-242. 14. Ковальчук I. С. Аналіз економічного розвитку малого підприємництва в Україні. Економічні науки. 2017. Вип. 1 (16). Ч. 1. С. 32-40.

\section{References}

1. Butenko A.I., Shlafman N.L. (2012). Napryamky derehulyatsii diyalnosti malykh pidpryyemnytskykh struktur v Ukrayii [Directions of deregulation of small business structures in Ukraine]. Visnyk ekonomichnoi nauky Ukrainy, 1 (21), pp. 30-33 [in Ukrainian]

2. Butenko A.I. Войнаренко, B.I. Lyashenko et al. (2011). Modernizatsiya melhanyzmiv rozvydku malaho ta serednoho biznesu [Modernization of small and medium business development mechanisms]. Donetsk, IIE of NAS of Ukraine. 326 p. [in Ukrainian].

3. Zhukov S., Dyuhovanets O., Balko O. (2019). Male pidpryyemnytstvo v Ukrayini: rol, stan, I perspektyvy rozvydku $\mathrm{v}$ period sitsiakno-ekonomichnykh potryasin. [Small business in Ukraine: role, state and prospects of development in the period of socio-economic shocks]. Visnyk ekonomichnoi nauky Ukrainy, 1 (36), pp. 40-43 [in Ukrainian].

4. Tolmachova G.F. (2015). Male i serednye pidpryyemnytstvj yak chynnyk vylhodu economiky Donbasy z kryzy [Small and medium business as a factor in the exit of the Donbass economy from the crisis]. Visnyk ekonomichnoi nauky Ukrainy, 1, pp. 146-154 [in Ukrainian].

5. Tolmachova G.F., Lyashenko V.I., Kolesnikova G.V. (2015). Rehulyuvannya rozvytku maloho i serednoho pidpryyemnytstva dosvid zarybizhnykh krayin dlya Ukrayiny [Regulation of small and medium business development: the experience of foreign countries for Ukraine]. Ekonomichnyi visnyk Donbasu - Economic Herald of the Donbas, 1 (47), pp. 157-185 [in Ukrainian].

6. Bolgarin P.N., Ilyashenko S.N. (2013). Analiz rynokhnykh vozmozhnostey razvitiya truboprokatnoho proizvodstva na PAO "SMNPO” im. M.V. Frynze” [Analysis of market opportunities for the development of pipe rolling production at PJSC "SMNPO IM. M.V. FRUNZE"]. Marketing and innovation management, 1, pp. 13-33 [in Russian].

7. Strilchuk R.M. (2016). Upravlinnya stratehichnymy mozhlyvostyamy mashynobudivnykh pidpryyimstv. [Management of strategic opportunities of machine-building enterprises]. Doctor's thesis. Lutsk, Lutsk National University tech. un-t. 226 p. [in Ukrainian].

8. Stratehiia rozvytku maloho y serednoho pidpryiemny-tstva v Ukraini na period do 2020 roku: Rozporiadzhennia KMU vid 24 travnia 2017 roku № 504-r [Strategy for the development of small and medium enterprises in Ukraine for the period up to 2020: Order of the Cabinet of Ministers of May 24, 2017 № 504-r]. Retrieved from http:// zakon2.rada.gov.ua/laws/show/145-2013-\%D1\%80 [in Ukrainian].

9. Stratehiia rozvytku maloho y serednoho pidpryiemny-tstva v Ukraini na period do 2020 roku: Rozporiadzhennia KMU vid 24 travnia 2017 roku № 504-r [Strategy for the development of small and medium enterprises in Ukraine until 2020: Order of the Cabinet of Ministers of May 24, 2017 № 504-r]. Retrieved from http://zakon2. rada.gov.ua/laws/show/504-2017-\%D1 \% 80 [in Ukrainian].

10. Main Department of Statistics in Donetsk Region Retrieved from http://donetskstat.gov.ua/statinform1/index.php [in Ukrainian].

11. Tax Code of Ukraine [Electronic resource]: Law of Ukraine of December 2, 2010 № 2755-VI. Retrieved from http: //zakon3.rada. gov.ua/laws/show/2755-17/ page4 [in Ukrainian].

12. Zhadko K. S. (Ed.). (2019). Organization of production and marketing activities of small and medium business. Dnipro, UMSF [in Ukrainian].

13. Chechetova-Terashvili T.M. (2013). Stratehichnyy analiz rozvydky maloho pidpryyemnystva v Kharkovi. Strategic analysis of small business development in Kharkiv]. Business Inform, 8, pp. 237-242. [in Ukrainian].

14. Kovalchuk I.S. (2017). Analiz ekonomichnoho rozvytku maloho pidpryyemnytstva v Ukrayini. [Analysis of economic development of small business in Ukraine]. Economic sciences, 1 (16), pp. 32-40 [in Ukrainian].

Коритько Т. Ю., Осадча Н. В., Толмачова Г. Ф. Проблеми розвитку малого та середнього бізнесу

Статтю присвячено діагностиці основних тенденцій та характеристиці проблем розвитку малого і середнього бізнесу в Донецькій області. Малий та середній бізнес - найбільш динамічніший елемент структури національної економіки та вагома складова ії системи економічних відносин. Він сприяє встановленню конкурентних засад, оскільки $є$ антимонопольним за своєю економічною суттю. Мале та середнє підприємництво як провідний сектор ринкової економіки, забез- 
печуючи ринок товарами та послугами, є автономним у здійсненні своєї господарської діяльності, розпоряджається готовою продукцією та прибутком, який залишається після сплати податків та інших зобов’язань.

Проведено аналіз основних показників, що визначають стан малого та середнього бізнесу Донецької області: кількості зареєстрованих підприємницьких осіб, частки малого та середнього бізнесу в економіці, кількості зайнятих осіб у малому та середньому бізнесі. В ході проведення SWOT-аналізу підприємств малого та середнього бізнесу Донецької області визначено сильні та слабкі сторони, можливості розвитку та загрози. Саме вони потребують найбільшої уваги і концентрації зусиль регіональної влади для їх усунення. Оцінюючи можливості, встановлюється потенційна привабливість Донецької області та ймовірність їх реалізації, а також те, чи заплановані вигоди можуть перевершити ймовірні втрати внаслідок реалізації можливостей. Іноді можливості можуть нести в собі як велику привабливість, так і великий ризик. Залежно від ситуації один і той самий чинник здатний бути як загрозою, так і можливістю. На основі проведення PESTаналізу визначено вплив зовнішніх факторів на діяльність підприємств малого та середнього бізнесу. Зазначено, що упродовж тривалого періоду розвиток малого та середнього підприємництва уповільнюється негативно діючими чинниками: кризовим станом вітчизняного товарного виробництва, зростанням цін, інфляцією, низьким рівнем платоспроможності населення, корупцією тощо.

Ключові слова: мале підприємництво, суб'єкт малого підприємництва, SWOT-аналіз, PEST-аналіз, середній бізнес.

Korytko T., Osadcha N., Tolmachova A. Problems of Small and Medium Business Development

The article is devoted to the diagnosis of the main trends and characteristics of the problems of small and medium business development in the Donetsk region. Small and medium business is the most dynamic element of the structure of the national economy and an important component of its system of economic relations. It contributes to the establishment of competitive principles, as it is antitrust in nature. Small and medium enterprises, as the leading sector of the market economy, providing the market with goods and services, are autonomous in carrying out their economic activities, dispose of finished products and profits that remain after taxes and other obligations. The analysis of the main indicators that determine the state of small and medium business in Donetsk region: the number of registered entrepreneurs, the share of small and medium business in the economy, the number of employees in small and medium business. A SWOT-analysis of small and medium-sized businesses in Donetsk region was conducted and its strengths and weaknesses, development opportunities and threats were identified. They need the greatest attention and concentration of efforts of regional authorities to eliminate them. Assessing the opportunities, the potential attractiveness of the Donetsk region and the probability of their realization, as well as whether the planned benefits may outweigh the probable losses due to the realization of opportunities. Sometimes opportunities can carry both great attractiveness and great risk. Depending on the situation, the same factor can be both a threat and an opportunity. Based on the PEST-analysis, the influence of external factors on the activities of small and medium enterprises is determined. It is noted that over a long period of time the development of small and medium enterprises is slowed down by negative factors: the crisis of domestic commodity production, rising prices, inflation, low solvency, corruption and more.

Keywords: small business, small business entity, SWOT-analysis, PEST-analysis, medium business.

Корытько Т. Ю., Осадчая Н. В., Толмачева А. Ф. Проблемы развития малого и среднего бизнеса

Статья посвящена диагностике основных тенденций и характеристике проблем развития малого и среднего бизнеса в Донецкой области. Малый и средний бизнес - наиболее динамичный элемент структуры национальной экономики и весомая составляющая ее системы экономических отношений. Он способствует установлению конкурентных основ, поскольку является антимонопольным по своей экономической сути. Малое и среднее предпринимательство как ведущий сектор рыночной экономики, обеспечивая рынок товарами и услугами, является автономным в осуществлении своей хозяйственной деятельности, распоряжается готовой продукцией и прибылью, которая остается после уплаты налогов т других обязательств. Проведен анализ основных показателей, определяющих состояние малого и среднего бизнеса Донецкой области: количества зарегистрированных предпринимательских лиц, доли малого и среднего бизнеса в экономике, количества занятых лиц в малом и среднем бизнесе. Проведен SWOT-анализ предприятий малого и среднего бизнеса Донецкой области и определены его сильные и слабые стороны, возможности развития и угрозы. Именно они требуют наибольшего внимания и концентрации усилий региональных властей по их устранению. Оценивая возможности, устанавливается возможная привлекательность Донецкой области и вероятность их реализации, а также то, запланированные выгоды могут ли превзойти вероятные потери вследствие реализации возможностей. Иногда возможности могут нести в себе как большую привлекательность, так и большой риск. В зависимости от ситуации один и тот же фактор способен быть как угрозой, так и возможностью. На основе проведения PEST-анализа определено влияние внешних факторов на деятельность предприятий малого и среднего бизнеса. Отмечено, что на протяжении длительного периода развитие малого и среднего предпринимательства замедляется негативно действующими факторами: кризисным состоянием отечественного товарного производства, ростом цен, инфляцией, низким уровнем платежеспособности населения, коррупцией.

Ключевые слова: малое предпринимательство, субъект малого предпринимательства, SWOT-анализ, PEST-анализ, средний бизнес.

Стаття надійшла до редакції 18.05.2020

Прийнято до друку 11.06.2020 